\title{
Survivin selective inhibitor YM155 induce apoptosis in SK-NEP-1 Wilms tumor cells
}

Yan-Fang Tao ${ }^{1 \dagger}$, Jun Lu ${ }^{1 \dagger}$, Xiao-Juan Du², Li-Chao Sun ${ }^{3}$, Xuan Zhao ${ }^{4}$, Liang Peng ${ }^{5}$, Lan Cao ${ }^{1}$, Pei-Fang Xiao', Li Pang ${ }^{1}$, Dong $\mathrm{Wu}^{1}$, Na Wang ${ }^{1}$, Xing Feng ${ }^{1}$, Yan-Hong $\mathrm{Li}^{1}$, Jian $\mathrm{Ni}^{6}$, Jian Wang ${ }^{1 *}$ and Jian Pan ${ }^{1 *}$

\begin{abstract}
Background: Survivin, a member of the family of inhibitor of apoptosis proteins, functions as a key regulator of mitosis and programmed cell death. YM155, a novel molecular targeted agent, suppresses survivin, which is overexpressed in many tumor types. The aim of this study was to determine the antitumor activity of YM155 in SK-NEP-1 cells.

Methods: SK-NEP-1 cell growth in vitro and in vivo was assessed by MTT and nude mice experiments. Annexin V/ propidium iodide staining followed by flow cytometric analysis was used to detect apoptosis in cell culture. Then gene expression profile of tumor cells treated with YM155 was analyzed with real-time PCR arrays. We then analyzed the expression data with MEV (Multi Experiment View) cluster software. Datasets representing genes with altered expression profile derived from cluster analyses were imported into the Ingenuity Pathway Analysis tool.

Results: YM155 treatment resulted in inhibition of cell proliferation of SK-NEP-1cells in a dose-dependent manner. Annexin V assay, cell cycle, and activation of caspase-3 demonstrates that YM155 induced apoptosis in SK-NEP-1 cells. YM155 significantly inhibited growth of SK-NEP-1 xenografts (YM155 $5 \mathrm{mg} / \mathrm{kg}: 1.45 \pm 0.77 \mathrm{~cm}^{3}$; YM155 $10 \mathrm{mg} /$ $\mathrm{kg}: 0.95 \pm 0.55 \mathrm{~cm}^{3}$ ) compared to DMSO group (DMSO: $3.70 \pm 2.4 \mathrm{~cm}^{3}$ ) or PBS group cells (PBS: $3.78 \pm 2.20 \mathrm{~cm}^{3}$, ANOVA P < 0.01). YM155 treatment decreased weight of tumors (YM155 $5 \mathrm{mg} / \mathrm{kg}: 1.05 \pm 0.24 \mathrm{~g}$; YM155 $10 \mathrm{mg} / \mathrm{kg}$ : $0.72 \pm 0.17 \mathrm{~g}$ ) compared to DMSO group (DMSO: $2.06 \pm 0.38 \mathrm{~g}$ ) or PBS group cells (PBS: $2.36 \pm 0.43 \mathrm{~g}$, ANOVA P < 0.01). Real-time PCR array analysis showed between Test group and control group there are 32 genes significantly up-regulated and 54 genes were significantly down-regulated after YM155 treatment. Ingenuity pathway analysis (IPA) showed cell death was the highest rated network with 65 focus molecules and the significance score of 44. The IPA analysis also groups the differentially expressed genes into biological mechanisms that are related to cell death, cellular function maintenance, cell morphology, carbohydrate metabolism and cellular growth and proliferation. Death receptor signaling (3.87E-19), TNFR1 signaling, induction of apoptosis by HIV1, apoptosis signaling and molecular mechanisms of cancer came out to be the top four most significant pathways. IPA analysis also showed top molecules up-regulated were BBC3, BIRC3, BIRC8, BNIP1, CASP7, CASP9, CD5, CDKN1A, CEBPG and COL4A3, top molecules down-regulated were ZNF443, UTP11L, TP73, TNFSF10, TNFRSF1B, TNFRSF25, TIAF1, STK17A, SST and SPP1, upstream regulator were NR3C1, TP53, dexamethasone, TNF and Akt.

(Continued on next page)
\end{abstract}

\footnotetext{
*Correspondence: wj196312@vip.163.com; panjian2008@163.com

${ }^{\dagger}$ Equal contributors

'Department of Hematology and Oncology, Children's Hospital of Soochow

University, Suzhou, China

Full list of author information is available at the end of the article
}

\section{Biomed Central}

(c) 2012 Tao et al.; licensee BioMed Central Ltd. This is an Open Access article distributed under the terms of the Creative Commons Attribution License (http://creativecommons.org/licenses/by/2.0), which permits unrestricted use, distribution, and reproduction in any medium, provided the original work is properly cited. 
(Continued from previous page)

Conclusions: The present study demonstrates that YM155 treatment resulted in apoptosis and inhibition of cell proliferation of SK-NEP-1 cells. YM155 had significant role and little side effect in the treatment of SK-NEP-1 xenograft tumors. Real-time PCR array analysis firstly showed expression profile of genes dyes-regulated after YM155 treatment. IPA analysis also represents new molecule mechanism of YM155 treatment, such as NR3C1 and dexamethasone may be new target of YM155. And our results may provide new clues of molecular mechanism of apoptosis induced by YM155.

Keywords: YM155, SK-NEP-1, Survivin, Apoptosis, Real-time PCR array

\section{Background}

Wilms tumor (WT) is the most common malignant neoplasm of the urinary tract in children [1]. Although it is curable with long-term survival, the combination of surgery, chemotherapy and often radiotherapy in some cases results in severe complications in adulthood [2]. Therefore, novel therapeutic strategies that would decrease treatment burden and improve outcome for high risk patients are required. We evaluated the efficacy of YM155, an inhibitor of survivin, to inhibit Wilms tumor development in xenografts models.

Overexpressed survivin can be detected in virtually every human tumor, but undetectable or present at very low levels in most normal adult tissues [3-5]. A 'tumorspecific' expression of survivin is predominantly dictated at the level of transcription, and that survivin gene expression may be globally 'deregulated' in tumors, in vivo $[4,6,7]$. Accordingly, survivin promoter activity is basically silent in normal cells, but strongly activated in tumor cells, and this occurs independently of cellular heterogeneity, mitotic status, or genetic makeup. The differential expression of the survivin gene in normal versus tumor cells is so dramatic that therapeutic strategies to drive tumor-specific expression of suicidal genes under the control of the survivin promoter have now advanced to preclinical stages in a number of settings [3,5-9].

YM155, a novel small-molecule survivin suppressant, has been shown to suppress survivin with little effect on expression levels of other IAP family or Bcl-2 related proteins [10]. YM155 has been demonstrated antitumor activity, with survivin suppression and tumor cell apoptosis, in various human cancer models [6,8,10-17]. Survivin is the smallest member of the Inhibitor of Apoptosis (IAP) gene family. Originally described as cell survival factors that target caspase, we now know that IAPs have a much broader portfolio of functions, encompassing signaling pathways, cell division, metabolism and adaptation to unfavorable environments. Survivin embodies this multifunctional diversity, and compelling data accumulated over a decade have elucidated many of its essential roles as a regulator of mitosis [17], a broad cytoprotective factor $[18,19]$, and an effector of cellular adaptation to stress [20,21]. These disparate functions rely on hosts of regulated interactions that involve survivin and multiple protein partners, including tubulin $[22,23]$ and various chromosomal passenger proteins in the control of mitosis, other IAP family members to counteract apoptosis, and Heat Shock Proteins in the modulation of the cellular stress response. These 'survivin networks' are dramatically exploited in cancer, and survivin is unanimously viewed as one of the most prominent cancer genes.

In the present study, the antitumor effect of YM155 have been evaluated in human SK-NEP-1 Wilms tumor cells and xenograft models to further characterize its preclinical efficacy, and the molecular mechanism was exploited with real-time PCR arrays.

\section{Methods}

\section{Cell and culture conditions}

SK-NEP-1 Human kidney (Wilm's Tumor) cell line obtained from the American Type Culture Collection (ATCC) was maintained in the Maccyo'5 (Life Technologies Inc., Gaithersburg, MD, USA) supplemented with $20 \%$ heat-inactivated fetal bovine serum (Invitrogen Co., NY, USA) in a humidified incubator with $5 \% \mathrm{CO}_{2}$ at $37^{\circ} \mathrm{C}$. YM155 (Cat: S1130 Selleck Chemicals, West Paterson, NJ, USA) was dissolved in DMSO (Cat: D4540 SigmaAldrich, St. Louis, MO, USA)

\section{Cell proliferation}

Sk-NEP-1 cells $\left(2 \times 10^{4}\right)$ were seeded in 96-well plates overnight and incubated with DMSO, $1 \mathrm{nM}$ YM155, or increasing concentrations of YM155 (0.005, 0.01, 0.02, $0.04,0.08,0.16,0.32,0.64$ or $1.28 \mu \mathrm{M})$ for 24 hours. The volume of DMSO added to the vehicle treated wells was the same as that added to the drug treated wells. Each drug concentration was performed in four replicate wells. 20uLMTT (3-(4, 5-dimethylthiazol-2-yl)-2, 5diphenyltetrazolium bromide) solution $(5 \mathrm{mg} / \mathrm{ml})$ was added to each well and incubated at $37^{\circ} \mathrm{C}$ for a further 4 hours. Then $200 \mathrm{uL}$ of DMSO was added to each well after the medium was removed. The optical density (OD) values were measured at $490 \mathrm{~nm}$ on a scanning multi-well spectrophotometer (BioRad Model 550, 
USA). Compared with the control group, the relative survival rate of remained cells was calculated from the absorbance values. Cell proliferation was calculated as a percentage of the DMSO- treated control wells with IC50 values derived after plotting proliferation values on a logarithmic curve.

\section{Cell cycle analysis}

Cells were collected and washed with PBS for 5 minutes by centrifugation at $125 \times \mathrm{g}$. Cells were fixed with paraformaldehyde and transparented with $0.5 \%$ Triton X-100. Then cells were resuspended in a staining solution containing $1.5 \mu \mathrm{mol} / \mathrm{L}$ propidium iodide (P4170, SigmaAldrich, St. Louis, MO, USA) and $25 \mu \mathrm{g} / \mathrm{ml}$ RNase A and incubated for 30 minutes in $37^{\circ} \mathrm{C}$. The samples (10000 cells) were analyzed by fluorescence-activated cell sorting with a Beckman Gallios ${ }^{\mathrm{TM}}$ Flow Cytometer.

\section{Apoptosis assay}

Apoptosis assay was according to the manual operation of BD Annexin V Staining Kit (Cat: 556420, BD Biosciences, Franklin Lakes, NJ USA). Briefly, wash cells twice with cold PBS and then resuspend cells in $1 \times$ Binding Buffer at a concentration of $\sim 1 \times 10^{6}$ cells $/ \mathrm{ml}$. Transfer $100 \mu \mathrm{l}$ of the solution $\left(\sim 1 \times 10^{5}\right.$ cells $)$ to a $5 \mathrm{ml}$ culture tube. Add Annexin V and PI $5 \mu \mathrm{l} /$ test. Gently mix the cells and incubate for $15 \mathrm{~min}$ at RT in the dark. Add $400 \mu \mathrm{l}$ of $1 \times$ Binding Buffer to each tube. Analyze by flow cytometry as soon as possible (within 1 hour).

\section{Western blot analysis}

For western blot analysis, cellular proteins were extracted in $40 \mathrm{mM}$ Tris- $\mathrm{HCl}$ (pH 7.4) containing $150 \mathrm{mM} \mathrm{NaCl}$ and 1\% (v/v) Triton X-100, supplemented with a cocktail of protease inhibitors. Equal amounts of protein were resolved on 12\% SDS-PAGE gels, and then transferred to a PVDF membrane (Millipore, Bedford, MA). Blots were blocked and then probed with antibodies against Caspase 3 (1:1000,

Cell Signaling Technology, Inc. Danvers, MA), GAPDH (1:5000, Sigma, St. Louis, MO). After washing, the blots were incubated with horseradish peroxidaseconjugated secondary antibodies and visualized by enhanced chemiluminescence kit (Pierce, Rockford, IL). Protein bands were visualized after exposure of the membrane to Kodak X-ray film.

\section{Xenograft assays the treatment effect of YM155 in nude mice}

This study was carried out in strict accordance with the recommendations in the Guide for the Care and Use of Laboratory Animals of the National Institutes of Health. The protocol was approved by the Committee on the Ethics of Animal Experiments of Soochow university
(Permit Number: 2011-10-21). All surgery was performed under sodium pentobarbital anesthesia, and all efforts were made to minimize suffering. Female nu/nu mice, aged 4-6 weeks, obtained from the Jackson Laboratory (Vitalriver, China), were kept in Class 10000 Clean Room at the Laboratory Animal Center of Soochow University (http://dwzx.suda.edu.cn/pages/index. aspx.) SK-NEP-1 cells were subcutaneously injected into five nude mice every group. 10 days after injection, mice were treated with PBS, DMSO, YM155 $5 \mathrm{mg} / \mathrm{kg}$ and $10 \mathrm{mg} / \mathrm{kg}$ dose. During the next six weeks these mice were examined for subcutaneous tumor growth. The tumor volumes were calculated according to the following formula: volume $=$ length $\times$ width $^{2} / 2$. After the last treatment, the mice were killed and the tumor weight was measured.

\section{Real-time PCR array analysis}

For RNA extraction, cells were immediately submerged in $2 \mathrm{ml}$ Trizol (Invitrogen Co., NY, USA), stored at $-80^{\circ} \mathrm{C}$ until further processed. A volume of $1 \mathrm{ml}$ of each sample was spun at $4^{\circ} \mathrm{C}$ for $15 \mathrm{~min}$ at $12,000 \mathrm{~g}$ to remove debris and DNA, $1 \mathrm{ml}$ of supernatant was mixed with $200 \mathrm{ul}$ chloroform, shaken for 15 seconds, incubated at Room Temperature for 2-3 minutes and spun for 10 minutes at $12,000 \mathrm{~g}$ at $4^{\circ} \mathrm{C}$. RNA was precipitated by adding $500 \mathrm{ul}$ of the aqueous phase to an equal volume of isopropanol and spun at $14,000 \mathrm{~g}$ at $4^{\circ} \mathrm{C}$ for 10 minutes. RNA was washed with $75 \%$ ethanol, spun at $14,000 \mathrm{~g}$ at $4{ }^{\circ} \mathrm{C}$ for 10 minutes, dried and resuspended in $40 \mathrm{ul}$ DEPC-treated $\mathrm{H}_{2} \mathrm{O}$. The final RNA concentration was determined using a spectrophotometer (Nanodrop 2000) and the purity was assessed by agarose gel electrophoresis. CDNA synthesis was performed on $4 \mathrm{ug}$ of RNA in a $10 \mathrm{ul}$ sample volume using SuperScript II reverse transcriptase (Invitrogen Co., NY, USA) as recommended by the manufacturer. The RNA was incubated with $0.5 \mathrm{ug}$ of oligo(dT)12-18mers primers (Invitrogen Co., NY, USA) for 7 minutes at $70^{\circ} \mathrm{C}$ and then transferred onto ice. Then, $9 \mathrm{ul}$ of a master mix containing $4 \mathrm{ul}$ of SuperScript II buffer, 2 ul of $0.1 \mathrm{M} \mathrm{DTT}$, and $1 \mathrm{ul}$ each of dNTPs stock (10 mM), Rnasin (40 UI) and SuperScript II were added to the RNA sample, spun and incubated at $42^{\circ} \mathrm{C}$ for $60 \mathrm{~min}$ followed by $5 \mathrm{~min}$ at $70^{\circ} \mathrm{C}$ to inactivate the enzyme. CDNA was stored at $-20^{\circ} \mathrm{C}$. Realtime PCR array (SABioscience Human Apoptosis PCR Array PAHS-3012) analysis was performed in a total volume of $20 \mathrm{ul}$ including $2 \mathrm{ul}$ of cDNA, primers $(0.2 \mathrm{mM}$ each) and $10 \mathrm{ul}$ of SYBR Green mix (Roche Co., Basel, Switzerland.). Reactions were run on an Light cycler 480 using the universal thermal cycling parameters $\left(95^{\circ} \mathrm{C} 5 \mathrm{~min}, 45 \mathrm{cycles}\right.$ of $10 \mathrm{sec}$ at $95^{\circ} \mathrm{C}, 20 \mathrm{sec}$ at $60^{\circ} \mathrm{C}$ and $15 \mathrm{sec}$ at $72^{\circ} \mathrm{C}$; melting curve: $10 \mathrm{sec}$ at $95^{\circ} \mathrm{C}, 60 \mathrm{sec}$ at $60^{\circ} \mathrm{C}$ and continues melting). Results were obtained using the sequence detection software Light cycler 480 and 
analyzed using Microsoft Excel. For all samples melting curves were acquired for quality control purposes. For gene expression quantification, we used the comparative $\mathrm{Ct}$ method. First, gene expression levels for each sample were normalized to the expression level of the housekeeping gene encoding Glyceraldehydes 3-phosphate dehydrogenase (GAPDH) within a given sample $(-\Delta \mathrm{Ct})$; the relative expression of each gene was calculated with $10^{6}$ ${ }^{*} \log _{2}(-\Delta \mathrm{Ct})$.The difference between the YM155 treatment samples compared to the control samples was used to determine the $10^{6}{ }^{*} \log _{2}(-\Delta \mathrm{Ct})$. Statistical significance of the gene expression difference between the YM155 treatment and the control samples was calculated with the T-test using SPSS 11.5 software.

\section{Ingenuity pathway analysis (IPA)}

Datasets representing genes with altered expression profile derived from Real-time PCR array analyses were imported into the Ingenuity Pathway Analysis Tool (IPA Tool; Ingenuity $\mathrm{H}$ Systems, Redwood City, CA, USA; http://www.ingenuity.com). In IPA, differentially expressed genes are mapped to genetic networks available in the Ingenuity database and then ranked by score. The basis of the IPA program consists of the Ingenuity Pathway Knowledge Base (IPKB) which is derived from known functions and interactions of genes published in the literature. Thus, the IPA Tool allows the identification of biological networks, global functions and functional pathways of a particular dataset. The program also gives the significance value of the genes, the other genes with which it interacts, and how the products of the genes directly or indirectly act on each other, including those not involved in the microarray analysis. The networks created are ranked depending on the number of significantly expressed genes they contain and also list diseases that were most significant. A network is a graphical representation of the molecular relationships between molecules. Molecules are represented as nodes, and the biological relationship between two nodes is represented as an edge (line). All edges are supported by at least 1 reference from the literature, from a textbook, or from canonical information stored in the Ingenuity Pathways Knowledge Base.

\section{Statistical analysis}

At least three replicates for each experimental condition were performed, and the presented results were representative of these replicates. All values are presented as means \pm SEM. Student's paired t-test was applied to reveal statistical significances. $P$ values less than 0.05 were considered significant. Statistical analyses were performed using SPSS Software for Windows (version 11.5; SPSS, Inc., Chicago, IL).

\section{Results}

Growth inhibitory effect of YM155 on SK-NEP-1 cells

YM155 treatment resulted in inhibition of cell proliferation of SK-NEP-1cells in a dose-dependent manner (Figure 1B). 93\%, 85\%, 70\%, 55\% and 30\% cells were viable when $10 \mathrm{nM}, 20 \mathrm{nM}, 40 \mathrm{nM}, 80 \mathrm{nM}$ and $160 \mathrm{nM}$ YM155 treated 24 hours. So the IC50 of YM155 for SKNEP-1 cells was about 100nM. The adherence of SKNEP-1 cells was much inhibited by YM155-treatment. YM155 induced detachment of the cells from the dishes (Data not shown).

\section{YM155 induced apoptosis in SK-NEP-1 cells}

To confirm whether YM155 induces apoptosis in SKNEP-1 cells, we further investigated Annexin V assay, cell cycle, and activation of caspase-3 in SK-NEP-1 cells after YM155 treatment. The result showed that cells treated with YM155 50nM and 100nM for 6 and 12 hours, much more cells showed apoptotic feature
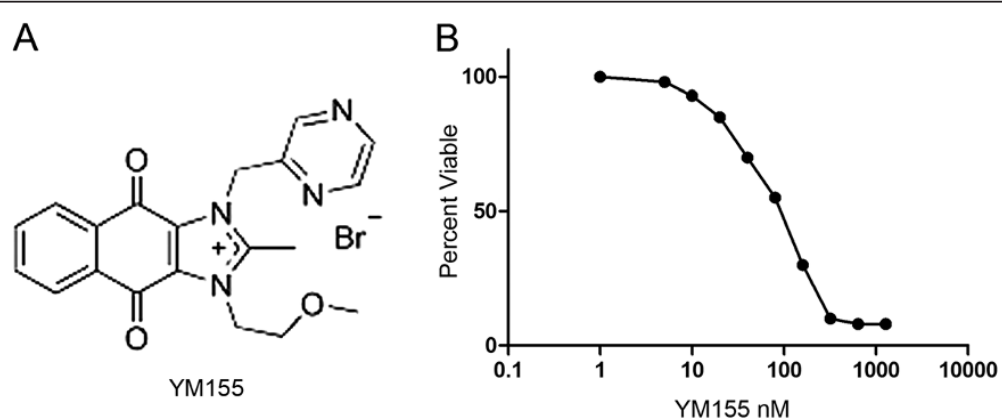

Figure 1 Growth inhibitory effect of YM155 on SK-NEP-1 cells. (A) Molecular Structure of YM155. (B) Proliferation and IC50 analysis of YM155. Sk-NEP-1 cells $\left(2 \times 10^{4}\right)$ were seeded in 96-well plates overnight and incubated with DMSO, 1 nM YM155, or increasing concentrations of YM155 $(0.005,0.01,0.02,0.04,0.08,0.16,0.32,0.64$ or $1.28 \mu \mathrm{M})$ for 24 hours. Compared with the control group, the relative survival rate of remained cells was calculated from the absorbance values. Cell proliferation was calculated as a percentage of the DMSO treated control wells with IC50 values derived after plotting proliferation values on a logarithmic curve. Experiments were performed in quadruplicate and repeated two times. 


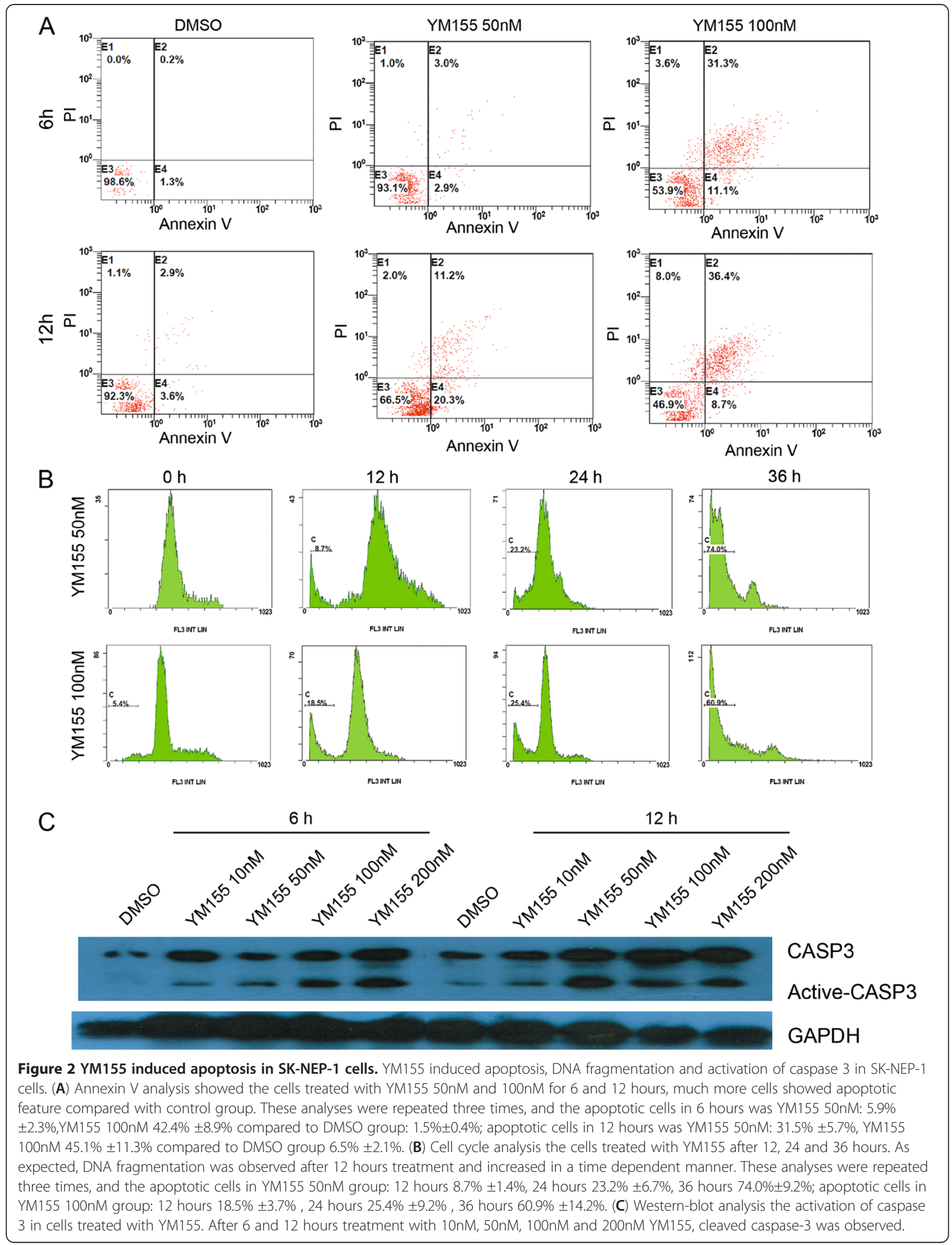


compared with control group (Figure 2A). These analyses were repeated three times, and the apoptotic cells in 6 hours was YM155 50nM: 5.9\% $\pm 2.3 \%$,YM155 $100 \mathrm{nM} 42.4 \% \pm 8.9 \%$ compared to DMSO group: $1.5 \%$ $\pm 0.4 \%$; apoptotic cells in 12 hours was YM155 $50 \mathrm{nM}$ : $31.5 \% \pm 5.7 \%$, YM155 $100 \mathrm{nM} 45.1 \% \pm 11.3 \%$ compared to DMSO group $6.5 \% \pm 2.1 \%$. Cell cycle was confirmed by Cell cycle assay (Figure 2B). As expected, DNA fragmentation was observed after 12 hours treatment and increased in a time dependent manner. These analyses were repeated three times, and the apoptotic cells in YM155 50nM group: 12 hours $8.7 \% \pm 1.4 \%, 24$ hours $23.2 \% \pm 6.7 \%$, 36 hours $74.0 \% \pm 9.2 \%$; apoptotic cells in YM155 100nM group: 12 hours $18.5 \% \pm 3.7 \%, 24$ hours $25.4 \% \pm 9.2 \%, 36$ hours $60.9 \% \pm 14.2 \%$. Moreover, to clearly demonstrate that YM155 causes apoptosis in SKNEP-1 cells, we assessed the molecular aspects of apoptosis, caspase-3, well recognized as a marker of apoptosis by western blot. After 6 and 12 hours treatment with $10 \mathrm{nM}, 50 \mathrm{nM}, 100 \mathrm{nM}$ and 200nM YM155, cleaved caspase- 3 was observed (Figure $2 \mathrm{C}$ ). This result is consistent with the data of Annexin V assay and cell cycle analysis, demonstrating that YM155 induced apoptosis in SK-NEP-1 cells. The results from both studies suggest that YM155 has promising antitumor activity against SK-NEP-1 cells.

\section{YM155 treatment inhibited growth of SK-NEP-1 xenograft} tumor in nude mice

We next assessed the impact of YM155 on the cell growth of SK-NEP-1 cells in nude mice. SK-NEP-1 cells were subcutaneously injected into five nude mice every group. 10 days after injection, mice were treated with PBS, DMSO, YM155 $5 \mathrm{mg} / \mathrm{kg}$ and $10 \mathrm{mg} / \mathrm{kg}$ dose. During the next six weeks these mice were examined for subcutaneous tumor growth. After the last treatment,
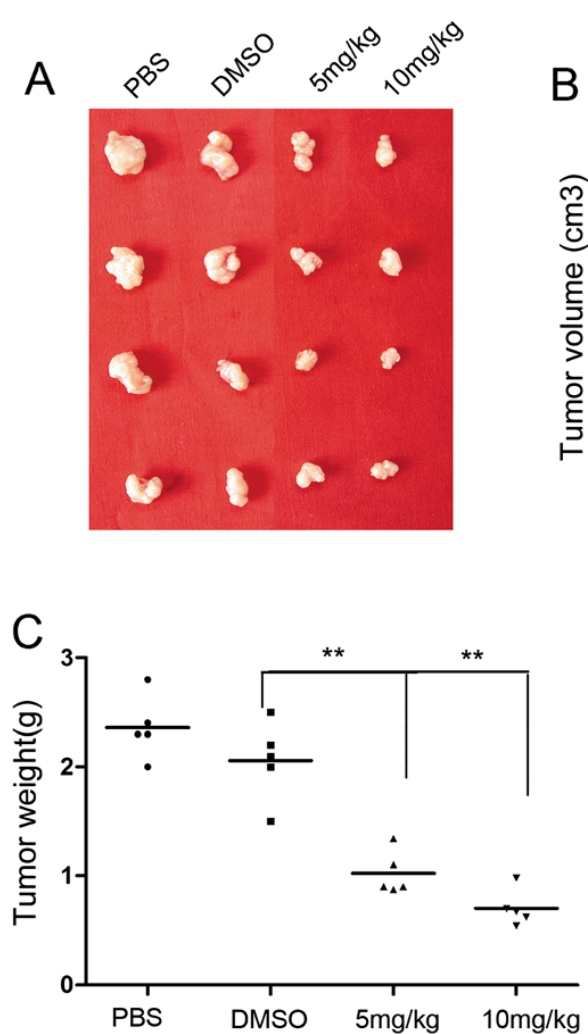

B
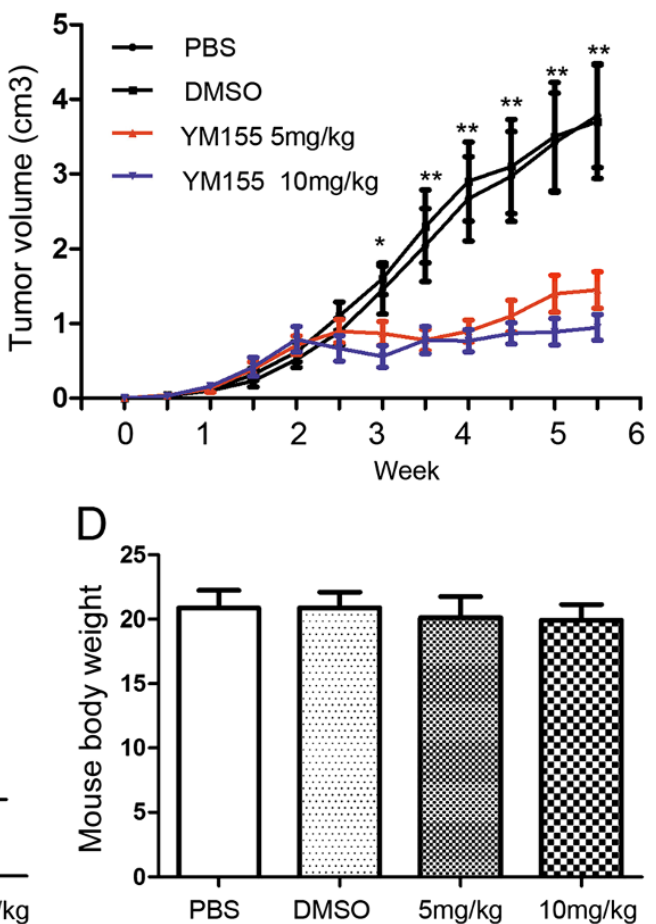

Figure 3 YM155 treatment inhibited growth of SK-NEP-1 xenograft tumor in nude mice. SK-NEP-1 cells were subcutaneously injected into five nude mice every group. 10 days after injection, mice were treated with PBS, DMSO, YM155 $5 \mathrm{mg} / \mathrm{kg}$ and $10 \mathrm{mg} / \mathrm{kg}$ dose. During the next six weeks these mice were examined for subcutaneous tumor growth. The tumor volumes were calculated according to the following formula: volume $=$ length $\times$ width $^{2} / 2$. After the last treatment, the mice were killed and the tumor weight was measured. (A) SK-NEP-1 xenograft tumors from the treatment experiment. (B) Growth curve of SK-NEP-1 cells treated with YM155, DMSO and PBS. YM155 significantly inhibited growth of SK-NEP-1 xenografts (YM155 $5 \mathrm{mg} / \mathrm{kg}: 1.45 \pm 0.77 \mathrm{~cm}^{3}$; YM155 $10 \mathrm{mg} / \mathrm{kg}: 0.95 \pm 0.55 \mathrm{~cm}^{3}$ ) compared to DMSO group (DMSO: $3.70 \pm 2.4 \mathrm{~cm}^{3}$ ) or PBS group cells (PBS: $3.78 \pm 2.20 \mathrm{~cm}^{3}$, ANOVA P < 0.01). (C) Tumor weight of the treatment experiment. YM155 treatment decreased weight of tumors (YM155 5 mg/kg: $1.05 \pm 0.24$ g; YM155 $10 \mathrm{mg} / \mathrm{kg}: 0.72 \pm 0.17 \mathrm{~g}$ ) compared to DMSO group (DMSO: $2.06 \pm 0.38 \mathrm{~g}$ ) or PBS group cells (PBS: $2.36 \pm 0.43 \mathrm{~g}$, ANOVA P < 0.01). (D) Body weight of nude mice in the treatment experiment. Body weight of nude mice treated with YM155 was almost same with control group (YM155 5 mg/kg:20.12 \pm 1.66 g; YM155 10 mg/kg: $19.92 \pm 1.72$ g) compared to DMSO group (DMSO: $20.88 \pm$ $1.83 \mathrm{~g}$ ) or PBS group cells (PBS: $20.66 \pm 1.37 \mathrm{~g}$, ANOVA P >0.05). 
the mice were killed and the tumor weight was measured. YM155 significantly inhibited growth of SK-NEP1 xenografts (YM155 $5 \mathrm{mg} / \mathrm{kg}: 1.45 \pm 0.77 \mathrm{~cm}^{3}$; YM155 $10 \mathrm{mg} / \mathrm{kg}: 0.95 \pm 0.55 \mathrm{~cm}^{3}$ ) compared to DMSO group (DMSO: $3.70 \pm 2.4 \mathrm{~cm}^{3}$ ) or PBS group cells (PBS: $3.78 \pm$ $2.20 \mathrm{~cm}^{3}$, ANOVA $\mathrm{P}<0.01$ Figure 3A, 3B). YM155 treatment decreased weight of tumors (YM155 $5 \mathrm{mg} / \mathrm{kg}$ : $1.05 \pm 0.24 \mathrm{~g}$; YM155 $10 \mathrm{mg} / \mathrm{kg}: 0.72 \pm 0.17 \mathrm{~g}$ ) compared to DMSO group (DMSO: $2.06 \pm 0.38 \mathrm{~g}$ ) or PBS group cells (PBS: $2.36 \pm 0.43 \mathrm{~g}$, ANOVA $\mathrm{P}<0.01$ Figure $3 \mathrm{C}$ ). We also observed that the body weight of nude mice treated with YM155 was almost same with control group (YM155 5 mg/kg:20.12 \pm 1.66 g; YM155 $10 \mathrm{mg} / \mathrm{kg}$ :
$19.92 \pm 1.72 \mathrm{~g}$ ) compared to DMSO group (DMSO: $20.88 \pm 1.83$ g) or PBS group cells (PBS: $20.66 \pm 1.37$ g, ANOVA P $>0.05$ Figure 3D). These studies support the view that YM155 had significant role and little side effect in the treatment of SK-NEP-1 xenograft tumors.

\section{Real-time PCR array analysis the dyes-regulated genes implicated into YM155 treatment}

In order to identify apoptosis and/or programmed cell death molecules implicated into the treatment with YM155, we used the SABioscience Human Apoptosis PCR Array PAHS-3012.We analyzed and clustered the expression of 370 key genes involved in apoptosis, or

Table 1 Genes up regulated in SK-NEP-1 cells treated with YM155 compared with DMSO control group

\begin{tabular}{|c|c|c|c|c|c|c|}
\hline & Gene & Symbol & +DMSO & +YM155 & Ratio & $P$ value \\
\hline 1 & TNF & Tumor necrosis factor & 0.052 & 3.274 & 62.850 & 0.0085 \\
\hline 2 & FOXO1 & Forkhead box $\mathrm{O} 1$ & 3.109 & 59.967 & 19.287 & 0.0091 \\
\hline 3 & IER3 & Immediate early response 3 & 53.221 & 795.891 & 14.955 & 0.0093 \\
\hline 4 & PEA15 & Phosphoprotein enriched in astrocytes 15 & 85.200 & 642.789 & 7.545 & 0.0105 \\
\hline 5 & CD5 & CD5 molecule & 0.079 & 0.584 & 7.405 & 0.0105 \\
\hline 6 & NDUFS3 & NADH dehydrogenase (ubiquinone) Fe-S protein 3, & 127.186 & 919.431 & 7.229 & 0.0106 \\
\hline 7 & TNFAIP3 & Tumor necrosis factor, alpha-induced protein 3 & 69.132 & 449.671 & 6.505 & 0.0109 \\
\hline 8 & NFKB1 & nuclear factor of kappa gene enhancer in B-cells 1 & 58.200 & 377.771 & 6.491 & 0.0109 \\
\hline 9 & CRYAB & Crystallin, alpha B & 7.704 & 49.315 & 6.401 & 0.0109 \\
\hline 10 & DDIT3 & DNA-damage-inducible transcript 3 & 134.710 & 768.681 & 5.706 & 0.0113 \\
\hline 11 & CRADD & CASP2 domain containing adaptor with death domain & 10.127 & 56.007 & 5.531 & 0.0114 \\
\hline 12 & BNIP1 & BCL2/adenovirus E1B $19 \mathrm{kDa}$ interacting protein 1 & 89.770 & 475.609 & 5.298 & 0.0115 \\
\hline 13 & $\mathrm{BBC} 3$ & $\mathrm{BCL} 2$ binding component 3 & 1.388 & 6.896 & 4.969 & 0.0118 \\
\hline 14 & NOX5 & NADPH oxidase, EF-hand calcium binding domain 5 & 0.213 & 1.057 & 4.953 & 0.0118 \\
\hline 15 & CASP7 & Caspase 7, apoptosis-related cysteine peptidase & 20.274 & 95.136 & 4.693 & 0.0120 \\
\hline 16 & PIM2 & Pim-2 oncogene & 29.093 & 118.888 & 4.087 & 0.0127 \\
\hline 17 & CEBPG & CCAAT/enhancer binding protein (C/EBP), gamma & 11.867 & 47.745 & 4.023 & 0.0128 \\
\hline 18 & $\mathrm{EDA}$ & Ectodysplasin A & 0.710 & 2.846 & 4.009 & 0.0128 \\
\hline 19 & SOCS2 & Suppressor of cytokine signaling 2 & 0.258 & 1.018 & 3.953 & 0.0129 \\
\hline 20 & CDKN1A & Cyclin-dependent kinase inhibitor 1A (p21, Cip1) & 124.431 & 479.383 & 3.853 & 0.0131 \\
\hline 21 & IL1A & Interleukin 1, alpha & 146.968 & 423.629 & 2.882 & 0.0155 \\
\hline 22 & $\mathrm{BIRC} 8$ & Baculoviral IAP repeat containing 8 & 0.248 & 0.692 & 2.785 & 0.0159 \\
\hline 23 & SERPINB2 & Serpin peptidase inhibitor, clade B member 2 & 0.136 & 0.362 & 2.659 & 0.0165 \\
\hline 24 & CASP9 & Caspase 9, apoptosis-related cysteine peptidase & 330.442 & 853.550 & 2.583 & 0.0169 \\
\hline 25 & LTB & Lymphotoxin beta (TNF superfamily, member 3) & 0.052 & 0.134 & 2.580 & 0.0170 \\
\hline 26 & PMAIP1 & Phorbol-12-myristate-13-acetate-induced protein 1 & 258.441 & 642.950 & 2.488 & 0.0175 \\
\hline 27 & NUPR1 & Nuclear protein, transcriptional regulator, 1 & 25.295 & 61.632 & 2.437 & 0.0179 \\
\hline 28 & $\mathrm{BIRC} 3$ & Baculoviral IAP repeat containing 3 & 97.141 & 232.642 & 2.395 & 0.0183 \\
\hline 29 & DIABLO & IAP-binding mitochondrial protein & 178.419 & 417.832 & 2.342 & 0.0187 \\
\hline 30 & LTBR & Lymphotoxin beta receptor & 120.546 & 280.744 & 2.329 & 0.0188 \\
\hline 31 & COL4A3 & Collagen, type IV, alpha 3 & 5.993 & 12.916 & 2.155 & 0.0208 \\
\hline 32 & $\mathrm{FOXO} 3$ & Forkhead box $\mathrm{O} 3$ & 34.671 & 71.488 & 2.062 & 0.0222 \\
\hline
\end{tabular}


Table 2 Genes down regulated in SK-NEP-1 cells treated with YM155 compared with DMSO control group

\begin{tabular}{|c|c|c|c|c|c|c|}
\hline & Gene & Symbol & +DMSO & +YM155 & Ratio & $P$ value \\
\hline 1 & HIPK2 & Homeodomain interacting protein kinase 2 & 31.640 & 11.619 & 0.367 & 0.0353 \\
\hline 2 & CD27 & CD27 molecule & 1.462 & 0.538 & 0.368 & 0.0353 \\
\hline 3 & PCBP4 & Poly $(\mathrm{rC})$ binding protein 4 & 9.419 & 3.481 & 0.370 & 0.0334 \\
\hline 4 & PAK7 & P21 protein (Cdc42/Rac)-activated kinase 7 & 0.120 & 0.044 & 0.370 & 0.0334 \\
\hline 5 & PPP1R13B & Protein phosphatase 1 , regulatory subunit $13 \mathrm{~B}$ & 75.280 & 27.926 & 0.371 & 0.0322 \\
\hline 6 & TP73 & Tumor protein p73 & 9.738 & 3.619 & 0.372 & 0.0321 \\
\hline 7 & RASA1 & RAS p21 protein activator 1 & 138.406 & 49.465 & 0.357 & 0.0315 \\
\hline 8 & CRYAA & Crystallin, alpha A & 0.210 & 0.079 & 0.375 & 0.0272 \\
\hline 9 & TIAF1 & TGFB1-induced anti-apoptotic factor 1 & 243.057 & 91.076 & 0.375 & 0.0242 \\
\hline 10 & CARD14 & Caspase recruitment domain family, member 14 & 37.791 & 13.412 & 0.355 & 0.0241 \\
\hline 11 & NOD1 & Nucleotide-binding domain containing 1 & 163.081 & 61.858 & 0.379 & 0.0214 \\
\hline 12 & TNFRSF1B & Tumor necrosis factor receptor superfamily $1 \mathrm{~B}$ & 45.110 & 17.323 & 0.384 & 0.0174 \\
\hline 13 & HIP1 & Huntingtin interacting protein 1 & 14.568 & 4.941 & 0.339 & 0.0174 \\
\hline 14 & UTP11L & UTP11-like, U3 small nucleolar ribonucleoprotein & 267.624 & 104.245 & 0.390 & 0.0118 \\
\hline 15 & SPP1 & Secreted phosphoprotein 1 & 2.389 & 0.801 & 0.335 & 0.0107 \\
\hline 16 & NME5 & NME/NM23 family member 5 & 0.217 & 0.073 & 0.335 & 0.0092 \\
\hline 17 & MYO18A & Myosin XVIIIA & 164.894 & 54.821 & 0.332 & 0.0087 \\
\hline 18 & PPP2R1B & Protein phosphatase 2 , regulatory subunit A & 9.768 & 3.887 & 0.398 & 0.0033 \\
\hline 19 & BAG1 & BCL2-associated athanogene & 70.273 & 28.001 & 0.398 & 0.0033 \\
\hline 20 & DAPK2 & Death-associated protein kinase 2 & 1.549 & 0.509 & 0.329 & 0.0023 \\
\hline 21 & TNFSF10 & Tumor necrosis factor (ligand) superfamily 10 & 2.596 & 0.844 & 0.325 & 0.0022 \\
\hline 22 & TNFRSF25 & Tumor necrosis factor receptor superfamily 25 & 10.685 & 4.340 & 0.406 & 0.0022 \\
\hline 23 & FOXL2 & Forkhead box L2 & 11.954 & 4.886 & 0.409 & 0.0021 \\
\hline 24 & CASP10 & Caspase 10 , apoptosis-related cysteine peptidase & 13.465 & 4.252 & 0.316 & 0.0021 \\
\hline 25 & CARD8 & Caspase recruitment domain family, member 8 & 3.835 & 1.209 & 0.315 & 0.0020 \\
\hline 26 & ALOX12 & Arachidonate 12-lipoxygenase & 9.725 & 3.039 & 0.312 & 0.0020 \\
\hline 27 & OPA1 & Optic atrophy 1 (autosomal dominant) & 172.500 & 71.720 & 0.416 & 0.0020 \\
\hline 28 & ERN2 & Endoplasmic reticulum to nucleus signaling 2 & 2.851 & 1.187 & 0.416 & 0.0020 \\
\hline 29 & STK17A & Serine/threonine kinase 17a & 111.835 & 46.583 & 0.417 & 0.0020 \\
\hline 30 & CARD9 & Caspase recruitment domain family, member 9 & 5.195 & 1.578 & 0.304 & 0.0020 \\
\hline 31 & GRM4 & Glutamate receptor, metabotropic 4 & 0.958 & 0.408 & 0.426 & 0.0020 \\
\hline 32 & SON & SON DNA binding protein & 547.934 & 234.409 & 0.428 & 0.0019 \\
\hline 33 & PLAGL2 & Pleiomorphic adenoma gene-like 2 & 69.972 & 30.027 & 0.429 & 0.0019 \\
\hline 34 & BIRC5 & Baculoviral IAP repeat containing 5 & 59.315 & 25.502 & 0.430 & 0.0019 \\
\hline 35 & FADD & Fas (TNFRSF6)-associated via death domain & 323.082 & 93.703 & 0.290 & 0.0019 \\
\hline 36 & NAIP & NLR family, apoptosis inhibitory protein & 44.019 & 12.731 & 0.289 & 0.0008 \\
\hline 37 & $\mathrm{BCL} 2$ & B-cell CLL/lymphoma 2 & 6.950 & 3.020 & 0.435 & 0.0008 \\
\hline 38 & ZNF443 & Zinc finger protein 443 & 8.149 & 3.583 & 0.440 & 0.0003 \\
\hline 39 & CASP8AP2 & Caspase 8 associated protein 2 & 43.673 & 19.445 & 0.445 & 0.0003 \\
\hline 40 & CUL5 & Cullin 5 & 134.969 & 60.117 & 0.445 & 0.0002 \\
\hline 41 & DAPK1 & Death-associated protein kinase 1 & 15.806 & 4.237 & 0.268 & $<0.0001$ \\
\hline 42 & NKX3-2 & NK3 homeobox 2 & 0.830 & 0.371 & 0.447 & $<0.0001$ \\
\hline 43 & SEMA4D & Itransmembrane domain semaphoring 4D & 9.709 & 2.589 & 0.267 & $<0.0001$ \\
\hline 44 & SST & Somatostatin & 0.694 & 0.179 & 0.258 & $<0.0001$ \\
\hline
\end{tabular}


Table 2 Genes down regulated in SK-NEP-1 cells treated with YM155 compared with DMSO control group (Continued)

\begin{tabular}{|c|c|c|c|c|c|c|}
\hline 45 & ALOX15B & Arachidonate 15-lipoxygenase, type B & 0.263 & 0.063 & 0.242 & $<0.0001$ \\
\hline 46 & $\mathrm{NOTCH} 2$ & Notch 2 & 930.886 & 223.933 & 0.241 & $<0.0001$ \\
\hline 47 & NLRC4 & NLR family, CARD domain containing 4 & 20.624 & 4.653 & 0.226 & $<0.0001$ \\
\hline 48 & PRKCA & Protein kinase C, alpha & 30.560 & 6.439 & 0.211 & $<0.0001$ \\
\hline 49 & APOE & Apolipoprotein E & 1.075 & 0.210 & 0.195 & $<0.0001$ \\
\hline 50 & NTF3 & Neurotrophin 3 & 0.295 & 0.044 & 0.150 & $<0.0001$ \\
\hline 51 & CARD17 & Caspase recruitment domain family, member 17 & 0.363 & 0.047 & 0.131 & $<0.0001$ \\
\hline 52 & MAPK8IP2 & Mitogen kinase 8 interacting protein 2 & 0.432 & 0.049 & 0.114 & $<0.0001$ \\
\hline 53 & F2 & coagulation factor II & 3.794 & 0.104 & 0.027 & $<0.0001$ \\
\hline 54 & CUL3 & cullin 3 & 1.228 & 0.059 & 0.048 & $<0.0001$ \\
\hline
\end{tabular}

programmed cell death with this PCR Array (Additional file 1). This array includes the TNF ligands and their receptors; members of the bcl-2 family, BIRC (baculoviral IAP repeat) domain proteins, CARD domain (caspase recruitment domain) proteins, death domain proteins, TRAF (TNF receptor-associated factor) domain proteins and caspases. We can easily and reliably analyze the expression of a focused panel of genes related to apoptosis with this array. Comparison of PCR results between Test group and control group showed that 32 genes were significantly up-regulated and 54 genes were significantly down-regulated after YM155 treatment (Table 1 and Table 2).

\section{Ingenuity pathway analysis the pathway regulated by YM155}

To investigate possible biological interactions of differently regulated genes, datasets representing genes with altered expression profile derived from real-time PCR array analyses were imported into the Ingenuity Pathway Analysis Tool. The list of differentially expressed genes analyzed by IPA revealed significant networks. Figure 4A represents the list of top 5 networks identified by IPA. Of these networks, cell death was the highest rated network with 65 focus molecules and the significance score of 44 (Figure 4D). The score is the probability that a collection of genes equal to or greater than the number in a network could be achieved by chance alone. A score of 3 indicates a 1/1000 chance that the focus genes are in a network not due to random chance. The IPA analysis also groups the differentially expressed genes into biological mechanisms that are related to cell death, cellular function maintenance, cell morphology, carbohydrate metabolism and cellular growth and proliferation (Figure 4B). Death receptor signaling (3.87E-19), TNFR1 signaling (2.34E-13), induction of apoptosis by HIV1 (2.67E-12), apoptosis signaling (6.56E-12) and molecular mechanisms of cancer (2.13E-11) came out to be the top four most significant pathways (Figure 4C). IPA analysis also showed top molecules up-regulated were
BBC3,BIRC3,BIRC8,BNIP1,CASP7,CASP9,CD5,CDKN1A, CEBPG and COL4A3, top molecules down-regulated were ZNF443, UTP11L, TP73, TNFSF10, TNFRSF1B, TNFRSF25,TIAF1,STK17A,SST and SPP1, upstream regulator were NR3C1, TP53, dexamethasone, TNF and Akt (Additional file 2). These upstream regulators such as TP53, TNF and Akt have already been reported as important regulators for the surviving network. TP53 and Akt have been widely investigated and there are hundreds of papers about the important roles in surviving pathway. But there is still no report about the relationship between $\mathrm{NR} 3 \mathrm{C} 1$, dexamethasone and survivin.

This work indicated firstly that NR3C1and dexamethasone may be upstream regulators in the survivin pathway. These results may provide new clues of molecular mechanism of apoptosis induced by YM155.

\section{Discussion}

Survivin is highly expressed in a broad range of solid tumors and hematological malignancies. Increased survivin expression in cancer patients is an unfavorable prognostic marker correlating with decreased overall survival in several malignancies, including non-small cell lung [24-26], gastric [27-31], colorectal [32-34], and breast carcinomas [35], neuroblastoma [36], prostate cancer [37], pancreatic cancer [38], hepatocellular carcinoma [39] and hematologic malignancies [40-44]. Increased survivin expression was also associated with increased risk of recurrence, lymph node invasion and metastasis. Finally, survivin overexpression may be a predictive factor to determine response to chemotherapy and radiotherapy in patients with bladder cancer, breast cancer, multiple myeloma and lymphoma. Studies have shown that survivin suppression induces tumor cell apoptosis and enhances sensitivity to apoptosis induced by existing anticancer drugs and other apoptotic stimuli. This work indicated that survivin also be an important target for human Wilms tumor cells. 


\section{A}

\section{Top Networks}

\begin{tabular}{llc} 
ID & Associated Network Functions & Score \\
\hline 1 & Cell Death, Embryonic Development, Renal Necrosis/Cell Death & 44 \\
2 & Cell Death, Tumor Morphology, Cellular Development & 25 \\
3 & Cell Death, Ophthalmic Disease, Developmental Disorder & 24 \\
4 & Cell Death, Inflammatory Response, Antigen Presentation & 20 \\
5 & Cell Cycle, Cellular Development, Cellular Growth and Proliferation & 18
\end{tabular}

B

Molecular and Cellular Functions

Name

Cell Death

p-value

Cellular Function and Maintenance

Cell Morphology

Carbohydrate Metabolism

Cellular Growth and Proliferation

$\begin{array}{cc}\text { p-value } & \# \\ 5.43 \mathrm{E}-37-6.27 \mathrm{E}-03 & 65 \\ 3.07 \mathrm{E}-11-6.27 \mathrm{E}-03 & 30 \\ 4.69 \mathrm{E}-11-6.27 \mathrm{E}-03 & 22 \\ 1.27 \mathrm{E}-10-6.27 \mathrm{E}-03 & 14 \\ 1.55 \mathrm{E}-10-6.27 \mathrm{E}-03 & 32\end{array}$

C

Analysis: API.YM 155 - 2012.08-18 00:14 Fif

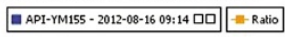

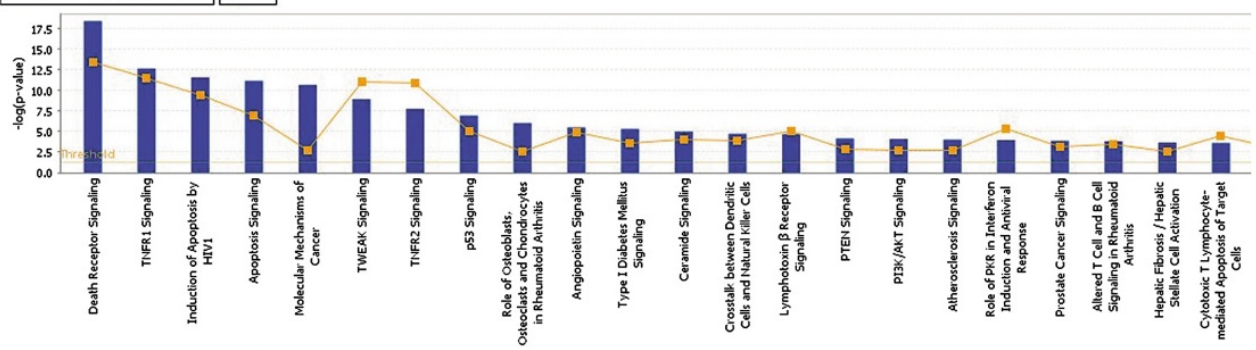

2000-2012 Ingenuity Systems, Inc. All tights resen

D

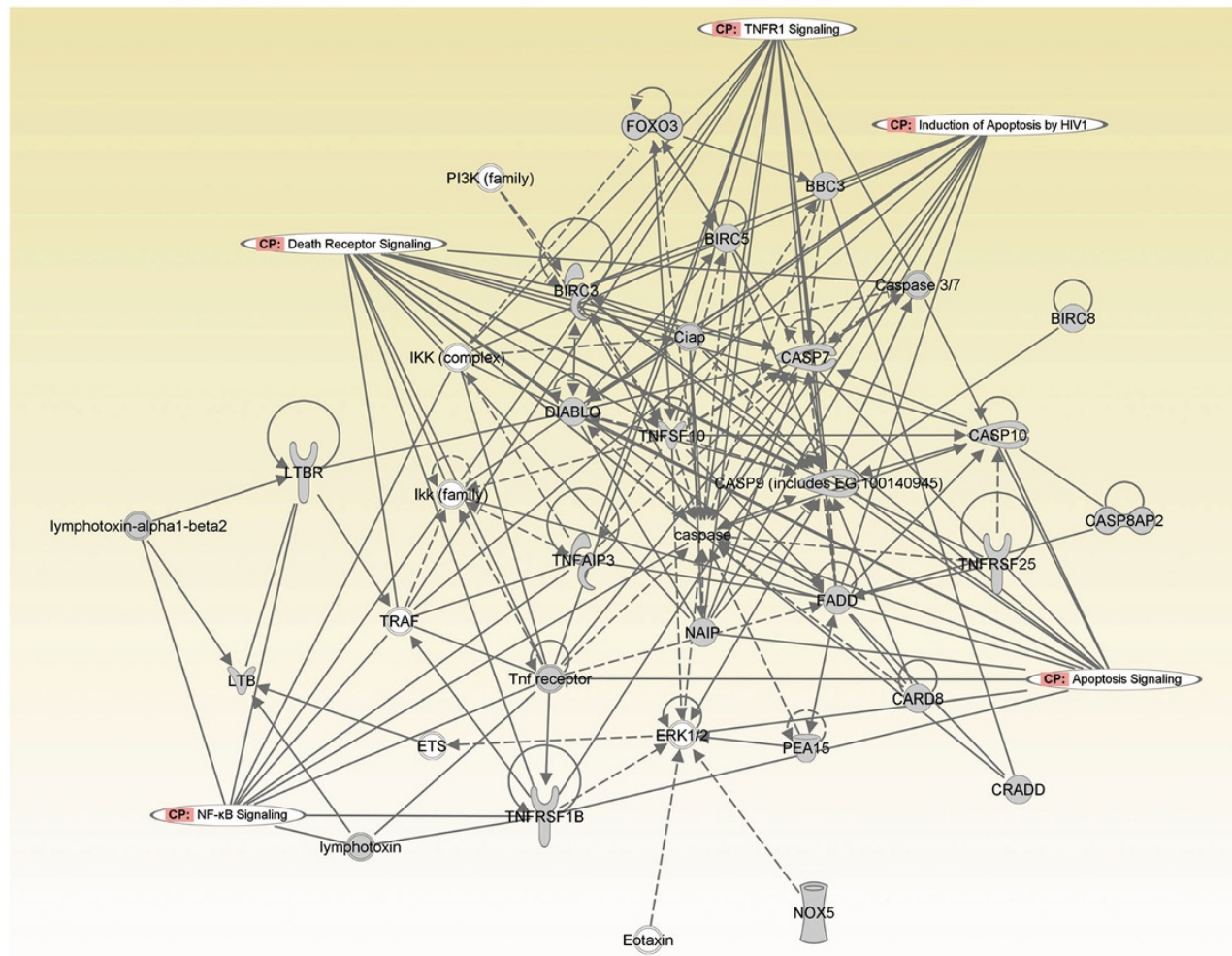

Figure 4 (See legend on next page.) 
(See figure on previous page.)

Figure 4 Ingenuity Pathways Analysis (IPA) summary. To investigate possible interactions of differently regulated genes, datasets representing 86 genes with altered expression profile obtained from real-time PCR arrays were imported into the Ingenuity Pathway Analysis Tool and the following data is illustrated: (A) The list of top five networks with their respective scores obtained from IPA. (B) The list of top five molecular and cellular functions with their respective scores obtained from IPA. (C) Toxicology pathway list in IPA analysis. The $x$-axis represents the top toxicology functions as calculated by IPA based on differentially expressed genes are highlighted and the $y$-axis represents the ratio of number of genes from the dataset that map to the pathway and the number of all known genes ascribed to the pathway. The yellow line represents the threshold of $p$ value, 0.05 as calculated by Fischer's test. (D) Most highly rated network in IPA analysis. The network representation of the most highly rated network. The genes that are shaded were determined to be significant from the statistical analysis. A solid line represents a direct interaction between the two gene products and a dotted line means there is an indirect interaction.

YM155 is a novel survivin suppressant that is currently in clinical development by Astellas Pharma, Inc. YM155 inhibited the growth of 119 human cancer cell lines, with the greatest activity in lines derived from nonHodgkin's lymphoma, hormone-refractory prostate cancer, ovarian cancer, sarcoma, non-small-cell lung cancer, breast cancer, leukemia and melanoma. The mean log growth inhibition of 50\% (GI50) value was $15 \mathrm{nM}$. A preclinical study showed that YM155 suppressed both survivin protein and mRNA expression. In a toxicologic study, short-term exposure at high blood concentrations caused cardiotoxicity in the form of atrioventricular. In this phase I study, YM155 seemed to be safe and welltolerated, with a maximum tolerated dose of $8.0 \mathrm{mg} / \mathrm{m}^{2}$ / d. Stable disease was achieved in nine patients. The data in this study indicate that the adverse reactions observed can be well-controlled by taking due caution and suggest that YM155 has more easily controllable toxicities compared with conventional cytotoxic anticancer drugs. This work also supports the view that YM155 had significant role and little side effect in the treatment of SK-NEP-1 xenograft tumors.

Real-time PCR Array System is the ideal tool for analyzing the expression of a focused panel of genes. The flexibility, simplicity, and convenience of standard SYBR Green PCR detection methodology make the PCR Array System accessible for routine use in any research laboratory [45]. In this study, we analyzed the dyes-regulated genes by YM155 with this powerful platform, Real-time PCR arrays.

Comparison of PCR results between Test group and control group showed that 32 genes were significantly up-regulated and 54 genes were significantly downregulated after YM155 treatment. Some genes, such as TNF, NFKB1, CDKN1A, CASP9, COL4A3, BIRC5 (survivin), BCL2, and DAPK1 have already been reported with YM155 treatment. There are also some other genes never reported with YM155 treatment and these genes have complicate functions far exceeds the apoptosis. These results consistent with the complicate roles of survivin in cancer biology. Survivin has been implicated in the regulation of the mitotic spindle checkpoint, from kinetic core to spindle assembly; it's over expression in cancer may allow cells with spindle defects or misaligned kinetic cores to continue through cell division. Recent studies also suggest that survivin plays a role in tumor progression and chemoresistance. Survivin has been shown to inhibit cell death induced by several anticancer agents, including paclitaxel [46], etoposide [47] and Tumor Necrosis Factor-a related apoptosis-inducing ligand $[47,48]$. In vitro and in vivo studies showed that inhibiting survivin reduces tumor growth potential and sensitizes tumor cells to chemotherapeutic agents, such paclitaxel, cisplatin $[14,49]$, etoposide, gamma irradiation and immunotherapy. To explore the molecule mechanism of YM155 treatment, we try to explore new target and "net work" of YM155 with a powerful platform, Ingenuity Pathway Analysis program.

The basis of the IPA program consists of the Ingenuity Pathway Knowledge Base (IPKB) which is derived from known functions and interactions of genes published in the literature. The IPA Tool allows the identification of biological networks, global functions and functional pathways of a particular dataset. The program also gives the significance value of the genes, the other genes with which it interacts, and how the products of the genes directly or indirectly act on each other, including those not involved in the microarray analysis. This work represents cell death was the highest rated network with 65 focus molecules and the significance score of 44. Death receptor signaling, TNFR1 signaling, induction of apoptosis by HIV1 ,apoptosis signaling and molecular mechanisms of cancer came out to be the top four most significant pathways. IPA analysis also showed top molecules up-regulated was BBC3 (PUMA). PUMA encodes a member of the BCL-2 family of proteins. This family member belongs to the BH3-only pro-apoptotic subclass. The protein cooperates with direct activator proteins to induce mitochondrial outer membrane permeabilization and apoptosis. It can bind to anti-apoptotic Bcl-2 family members to induce mitochondrial dysfunction and caspase activation. Because of its pro-apoptotic role, this gene is a potential drug target for cancer therapy and for tissue injury. IPA analysis also showed upstream regulators were NR3C1, TP53, dexamethasone, TNF and Akt. These upstream regulators such as TP53, TNF and Akt have already been reported as important 
regulators for the survivin network. TP53 and Akt have been widely investigated and there are hundreds of papers about the important roles in survivin pathway. But there is still no report about the relationship between $\mathrm{NR} 3 \mathrm{C} 1$, dexamethasone and survivin. $\mathrm{NR} 3 \mathrm{C} 1$ gene encodes glucocorticoid receptor, which can function both as a transcription factor that binds to glucocorticoid response elements in the promoters of glucocorticoid responsive genes to activate their transcription and as a regulator of other transcription factors. This receptor is typically found in the cytoplasm, but upon ligand binding, is transported into the nucleus. It is involved in inflammatory responses, cellular proliferation, and differentiation in target tissues. Dexamethasone gene encodes a member of the Ras superfamily of small GTPases and is induced by dexamethasone. The encoded protein is an activator of G-protein signaling and acts as a direct nucleotide exchange factor for Gi-Go proteins. This protein interacts with the neuronal nitric oxide adaptor protein CAPON, and a nuclear adaptor protein FE65, which interacts with the Alzheimer's disease amyloid precursor protein. This gene may play a role in dexamethasoneinduced alterations in cell morphology, growth and cellextracellular matrix interactions. Epigenetic inactivation of this gene is closely correlated with resistance to dexamethasone in multiple myeloma cells. This work indicated firstly that NR3Cland dexamethasone may be upstream regulators in the survivin pathway. These results may provide new clues of molecular mechanism of apoptosis induced by YM155.

\section{Conclusions}

The present study demonstrates that YM155 treatment resulted in apoptosis and inhibition of cell proliferation of SK-NEP-1cells. YM155 had significant role and little side effect in the treatment of SK-NEP-1 xenograft tumors. Real-time PCR array analysis firstly showed expression profile of genes dyes-regulated after YM155 treatment. IPA analysis also represents new molecule mechanism of YM155 treatment, such as NR3C1 and dexamethasone may be new target of YM155. And our results may provide new clues of molecular mechanism of apoptosis induced by YM155.

\section{Additional files}

Additional file 1: Cluster analysis the data from Real-time PCR arrays.

Additional file 2: Summary of IPA analysis.

\section{Competing interests}

The authors have no conflicts of interest to disclose.

\section{Authors' contributions}

PJ designed and directed the study. WJ drafted the manuscript. TYF and $L J$ finished the most of the experiments. $F X, Z X, P L, C L, X P F, P L$ and $L Y H$ coordinated data collection and quality control, and assisted in the interpretation of results. DXJ, SLC, WD and WN participated in acquiring laboratory data analysis. NJ participated in study design and coordination, data analysis and interpretation and drafted the manuscript. All authors read and approved the final manuscript

\section{Acknowledgements}

This work was supported by grants from the National Key Basic Research Program No. 2010CB933902, National Natural Science Foundation for youth No. 81100371, Natural Science Foundation of Jiangsu Province No. BK2011308, Universities Natural Science Foundation of Jiangsu Province No. $11 \mathrm{KJB} 320014$ and Talent's subsidy project in science and education of department of public health of Suzhou City No. SWKQ1020. Medical innovation team and leading talent of Jiang-su Province No. LJ201126. Major scientific and technological special project for "significant new drugs creation" No.2012ZX09103301-040.

\section{Author details}

'Department of Hematology and Oncology, Children's Hospital of Soochow University, Suzhou, China. ${ }^{2}$ Department of Gastroenterology, the 5th Hospital of Chinese PLA, Yin chuan, Ningxia Province, China. ${ }^{3}$ Department of Cell and Molecular Biology, Cancer Institute (Hospital), Chinese Academy of Medical Sciences, Peking Union Medical College, Beijing, China. ${ }^{4}$ Beijing Insititute for Drug Control, Beijing, China. ${ }^{5}$ Institute of Clinical Medical Science,

China-Japan Friendship Hospital, Beijing, China. ${ }^{6}$ Translational Research Center, Second Hospital, The Second Clinical School, Nanjing Medical

University, Nanjing, China.

Received: 29 August 2012 Accepted: 21 December 2012

Published: 26 December 2012

\section{References}

1. Smith MA, Morton CL, Phelps D, Girtman K, Neale G, Houghton PJ: SK-NEP1 and Rh1 are Ewing family tumor lines. Pediatr Blood Cancer 2008, 50(3):703-706.

2. Davenport KP, Blanco FC, Sandler AD: Pediatric malignancies: neuroblastoma, Wilm's tumor, hepatoblastoma, rhabdomyosarcoma, and sacroccygeal teratoma. Surg Clin North Am, 92(3):745-767.

3. Kita A, Nakahara T, Takeuchi M, Kinoyama I, Yamanaka K, Minematsu T, Mitsuoka K, Fushiki H, Miyoshi S, Sasamata M, et al: [Survivin supressant: a promising target for cancer therapy and pharmacological profiles of YM155]. Nihon Yakurigaku Zasshi, 136(4):198-203.

4. Ryan BM, O'Donovan N, Duffy MJ: Survivin: a new target for anti-cancer therapy. Cancer Treat Rev 2009, 35(7):553-562.

5. Arora R, Shuda M, Guastafierro A, Feng H, Toptan T, Tolstov $Y$, Normolle D, Vollmer LL, Vogt A, Domling A, et al: Survivin is a therapeutic target in merkel cell carcinoma. Sci Trans/ Med, 4(133):133ra-156ra.

6. Ghadimi MP, Young ED, Belousov R, Zhang Y, Lopez G, Lusby K, Kivlin C, Demicco EG, Creighton CJ, Lazar AJ, et al: Survivin is a viable target for the treatment of malignant peripheral nerve sheath tumors. Clin Cancer Res, 18(9):2545-2557.

7. Church DN, Talbot DC: Survivin in solid tumors: rationale for development of inhibitors. Curr Oncol Rep, 14(2):120-128.

8. Tyner JW, Jemal AM, Thayer M, Druker BJ, Chang BH: Targeting survivin and p53 in pediatric acute lymphoblastic leukemia. Leukemia, 26(4):623-632

9. Miura K, Fujibuchi W, Ishida K, Naitoh T, Ogawa H, Ando T, Yazaki N, Watanabe K, Haneda S, Shibata C, et al: Inhibitor of apoptosis protein family as diagnostic markers and therapeutic targets of colorectal cancer. Surg Today, 41(2):175-182

10. Yamanaka K, Nakata M, Kaneko N, Fushiki H, Kita A, Nakahara T, Koutoku H, Sasamata M: YM155, a selective survivin suppressant, inhibits tumor spread and prolongs survival in a spontaneous metastatic model of human triple negative breast cancer. Int $J$ Oncol, 39(3):569-575.

11. Correction: YM155, a Novel Small-Molecule Survivin Suppressant, Induces Regression of Established Human Hormone-Refractory Prostate Tumor Xenografts. Cancer Res, 72(15):3886.

12. Cheng Q, Ling X, Haller A, Nakahara T, Yamanaka K, Kita A, Koutoku H, Takeuchi M, Brattain MG, Li F: Suppression of survivin promoter activity by YM155 involves disruption of Sp1-DNA interaction in the survivin core promoter. Int J Biochem Mol Biol, 3(2):179-197.

13. Lai PC, Chen SH, Yang SH, Cheng CC, Chiu TH, Huang YT: Novel Survivin Inhibitor YM155 elicits Cytotoxicity in Glioblastoma Cell Lines with 
Normal or Deficiency DNA-Dependent Protein Kinase Activity. Pediatr Neonatol, 53(3):199-204.

14. Kumar B, Yadav A, Lang JC, Cipolla M, Schmitt AC, Arradaza N, Teknos TN, Kumar P: YM155 reverses cisplatin resistance in head and neck cancer by decreasing cytoplasmic survivin levels. Mol Cancer Ther.

15. Yoon DH, Shin JS, Jin DH, Hong SW, Jung KA, Kim SM, Hong YS, Kim KP, Lee $J \mathrm{~L}$, Suh $\mathrm{C}$, et al: The survivin suppressant YM155 potentiates chemosensitivity to gemcitabine in the human pancreatic cancer cell line MiaPaCa-2. Anticancer Res, 32(5):1681-1688.

16. Lamers F, Schild L, Koster J, Versteeg R, Caron HN, Molenaar JJ: Targeted BIRC5 silencing using YM155 causes cell death in neuroblastoma cells with low ABCB1 expression. Eur J Cancer, 48(5):763-771.

17. Nakahara T, Yamanaka K, Hatakeyama S, Kita A, Takeuchi M, Kinoyama I, Matsuhisa A, Nakano K, Shishido T, Koutoku H, et al: YM155, a novel survivin suppressant, enhances taxane-induced apoptosis and tumor regression in a human Calu 6 lung cancer xenograft model. Anticancer Drugs, 22(5):454-462

18. Chan KS, Wong CH, Huang YF, Li HY: Survivin withdrawal by nuclear export failure as a physiological switch to commit cells to apoptosis. Cell Death Dis, 1:e57.

19. Blanc-Brude OP, Yu J, Simosa H, Conte MS, Sessa WC, Altieri DC: Inhibitor of apoptosis protein survivin regulates vascular injury. Nat Med 2002, 8(9):987-994.

20. Faqing T, Zhi H, Liqun Y, Min T, Huanhua G, Xiyun D, Ya C: Epstein-Barr virus LMP1 initiates cell proliferation and apoptosis inhibition via regulating expression of Survivin in nasopharyngeal carcinoma. Exp Oncol 2005, 27(2):96-101.

21. Fortugno P, Beltrami E, Plescia J, Fontana J, Pradhan D, Marchisio PC, Sessa WC, Altieri DC: Regulation of survivin function by $\mathrm{Hsp} 90$. Proc Natl Acad Sci USA 2003, 100(24):13791-13796.

22. Zheng WE, Chen $H$, Yuan SF, Wu LL, Zhang W, Sun HY, Chen WJ: Overexpression of betalll-tubulin and survivin associated with drug resistance to docetaxel-based chemotherapy in advanced gastric cancer. J BUON, 17(2):284-290.

23. Rosa J, Canovas P, Islam A, Altieri DC, Doxsey SJ: Survivin modulates microtubule dynamics and nucleation throughout the cell cycle. Mol Biol Cell 2006, 17(3):1483-1493.

24. Ma L, Yue W, Zhang L, Wang Y, Zhang C, Yang X: [Clinical significance and diagnostic value of Survivin autoantibody in non-small cell lung cancer patients]. Zhongquo Fei Ai Za Zhi, 13(7):706-712.

25. Dai $C H$, Li J, Shi SB, Yu LC, Ge LP, Chen P: Survivin and Smac gene expressions but not livin are predictors of prognosis in non-small cell lung cancer patients treated with adjuvant chemotherapy following surgery. Jpn J Clin Oncol, 40(4):327-335.

26. Vaishlia NA, Zinov'eva MV, Sass AV, Kopantsev EP, Vinogradova TV, Sverdlov ED: [Increase of BIRC5 gene expression in non-small cell lung cancer and esophageal squamous cell carcinoma does not correlate with expression of genes SMAC/DIABLO and PML encoding its inhibitors]. Mol Biol (Mosk) 2008, 42(4):652-661.

27. Waligorska-Stachura J, Jankowska A, Wasko R, Liebert W, Biczysko M, Czarnywojtek A, Baszko-Blaszyk D, Shimek V, Ruchala M: Survivinprognostic tumor biomarker in human neoplasms-review. Ginekol Pol, 83(7):537-540

28. Amin AT, Shiraishi N, Ninomiya S, Tajima M, Inomata M, Kitano S: Increased mRNA expression of epidermal growth factor receptor, human epidermal receptor, and survivin in human gastric cancer after the surgical stress of laparotomy versus carbon dioxide pneumoperitoneum in a murine model. Surg Endosc, 24(6):1427-1433.

29. Song KY, Jung CK, Park WS, Park CH: Expression of the antiapoptosis gene Survivin predicts poor prognosis of stage III gastric adenocarcinoma. Jpn J Clin Oncol 2009, 39(5):290-296.

30. Bertazza L, Mocellin S, Marchet A, Pilati P, Gabrieli J, Scalerta R, Nitti D: Survivin gene levels in the peripheral blood of patients with gastric cancer independently predict survival. J Trans/ Med 2009, 7:111.

31. Vallbohmer D, Drebber U, Schneider PM, Baldus S, Bollschweiler E, Brabender J, Warnecke-Eberz U, Monig S, Holscher AH, Metzger R: Survivin expression in gastric cancer: Association with histomorphological response to neoadjuvant therapy and prognosis. J Surg Oncol 2009, 99(7):409-413

32. Kalliakmanis JG, Kouvidou C, Latoufis C, Kouvatseas G, Anagnostakis D, Papatheodoridis G, Koskinas J, Archimandritis A: Survivin expression in colorectal carcinomas: correlations with clinicopathological parameters and survival. Dig Dis Sci, 55(10):2958-2964

33. Xiaoyuan C, Longbang C, Jinghua W, Xiaoxiang G, Huaicheng G, Qun Z, Haizhu S: Survivin: a potential prognostic marker and chemoradiotherapeutic target for colorectal cancer. Ir J Med Sci. 179(3):327-335.

34. Abd El-Hameed A: Survivin expression in colorectal adenocarcinoma using tissue microarray. J Egypt Natl Canc Inst 2005, 17(1):42-50.

35. Nassar A, Sexton D, Cotsonis G, Cohen C: Survivin expression in breast carcinoma: correlation with apoptosis and prognosis. Appl Immunohistochem Mol Morphol 2008, 16(3):221-226.

36. Islam A, Kageyama H, Takada N, Kawamoto T, Takayasu H, Isogai E, Ohira M, Hashizume K, Kobayashi H, Kaneko Y, et al: High expression of Survivin, mapped to $17 \mathrm{q} 25$, is significantly associated with poor prognostic factors and promotes cell survival in human neuroblastoma. Oncogene 2000, 19(5):617-623.

37. Liu X, Gao R, Dong Y, Gao L, Zhao Y, Zhao L, Zhao X, Zhang H: Survivin gene silencing sensitizes prostate cancer cells to selenium growth inhibition. BMC Cancer, 10:418

38. Lee MA, Park GS, Lee HJ, Jung JH, Kang JH, Hong YS, Lee KS, Kim DG, Kim SN: Survivin expression and its clinical significance in pancreatic cancer. BMC Cancer 2005, 5:127.

39. Augello C, Caruso L, Maggioni M, Donadon M, Montorsi M, Santambrogio R, Torzilli G, Vaira V, Pellegrini C, Roncalli M, et al: Inhibitors of apoptosis proteins (IAPs) expression and their prognostic significance in hepatocellular carcinoma. BMC Cancer 2009, 9:125.

40. Small S, Keerthivasan G, Huang Z, Gurbuxani S, Crispino JD: Overexpression of survivin initiates hematologic malignancies in vivo. Leukemia, 24(11):1920-1926

41. Troeger A, Siepermann M, Escherich G, Meisel R, Willers R, Gudowius S, Moritz T, Laws HJ, Hanenberg H, Goebel U, et al: Survivin and its prognostic significance in pediatric acute B-cell precursor lymphoblastic leukemia. Haematologica 2007, 92(8):1043-1050.

42. Cong XL, Han ZC: Survivin and leukemia. Int J Hematol 2004, 80(3):232-238

43. Tamm I, Richter S, Oltersdorf D, Creutzig U, Harbott J, Scholz F, Karawajew L, Ludwig WD, Wuchter C: High expression levels of $x$-linked inhibitor of apoptosis protein and survivin correlate with poor overall survival in childhood de novo acute myeloid leukemia. Clin Cancer Res 2004. 10(11):3737-3744.

44. Ansell SM, Arendt BK, Grote DM, Jelinek DF, Novak AJ, Wellik LE, Remstein $E D$, Bennett CF, Fielding A: Inhibition of survivin expression suppresses the growth of aggressive non-Hodgkin's lymphoma. Leukemia 2004, 18(3):616-623

45. Schmittgen TD, Lee EJ, Jiang J: High-throughput real-time PCR. Methods Mol Biol 2008, 429:89-98

46. Hansen JB, Fisker N, Westergaard M, Kjaerulff LS, Hansen HF, Thrue CA, Rosenbohm C, Wissenbach M, Orum H, Koch T: SPC3042: a proapoptotic survivin inhibitor. Mol Cancer Ther 2008, 7(9):2736-2745.

47. Azuhata T, Scott D, Griffith TS, Miller M, Sandler AD: Survivin inhibits apoptosis induced by TRAIL, and the ratio between survivin and TRAIL receptors is predictive of recurrent disease in neuroblastoma. $J$ Pediatr Surg 2006, 41(8):1431-1440.

48. Entezari Heravi R, Hadizadeh F, Sankian M, Tavakol Afshari J, Taghdisi SM, Jafarian H, Behravan J: Novel selective Cox-2 inhibitors induce apoptosis in Caco-2 colorectal carcinoma cell line. Eur J Pharm Sci, 44(4):479-486.

49. Iwasa T, Okamoto I, Takezawa K, Yamanaka K, Nakahara T, Kita A, Koutoku H, Sasamata M, Hatashita E, Yamada Y, et al: Marked anti-tumour activity of the combination of YM155, a novel survivin suppressant, and platinumbased drugs. Br J Cancer, 103(1):36-42.

doi:10.1186/1471-2407-12-619

Cite this article as: Tao et al: Survivin selective inhibitor YM155 induce apoptosis in SK-NEP-1 Wilms tumor cells. BMC Cancer 2012 12:619. 